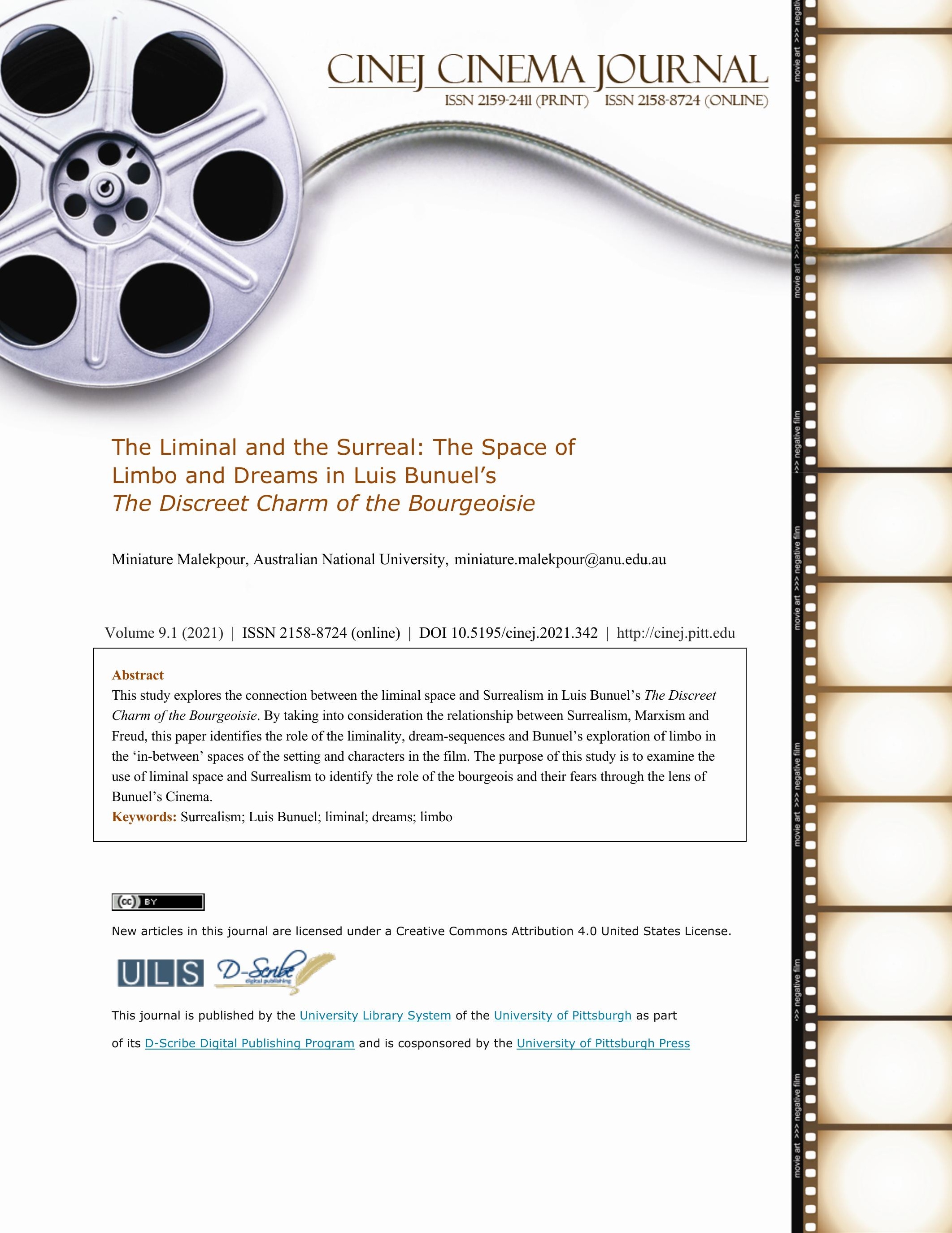




\section{The Liminal and the Surreal: The Space of Limbo and Dreams in Luis Bunuel's The Discreet Charm of the Bourgeoisie}

\section{Introduction}

Dreams and visions have been connected to some of the most powerful and direct experiences between the living and the dead, and the afterlife or other world (Schmitt, 1994). As part of its surreal transparency, the link between the dreams and death has crossed over culture, time, and space to manifest itself alongside traditional Shamanic journeys, in which dream states cross over into the unknown (Klaniczay \& Pócs, 2005).

Whether it is the dead who enter the liminal space of dreams or it is humans who explore the unknown through their unconscious state, this transient state becomes a rite of passage for either group.

Victor Turner's definition of liminality is generalized as a "betwixt and between" state, where the "individual begins in a state of separation from the community, after which follows the liminal state in which the rite is performed" (Turner, 1967). It is after this rite that the individual returns to the space of the community, leaving the ambiguous state of the liminal that marks their transition "from one status to another (Riviere, 2009, p.109.) The individual undergoes a state of transcendence, neither part of nor exiled from the community until that rite is completed, when they then are recognized as a member of that community. Turner himself has alluded to the link between liminality and death as belonging to the same condition, claiming that "the essential 
feature of these symbolizations is that the neophytes are neither living nor dead from one aspect, both living and dead from another. Their condition is one of ambiguity and paradox, a confusion of all the customary changes (Turner, 1967, p.94)

In Luis Bunuel's cinema, the individual (character) is able to transform their experience through the functional elements of separation and connection, formed in the spaces of the potential of becoming and engendering. This metamorphosis creates a third space, the liminal, which induces semantic and sensational feelings and motivations. By enhancing the liminal characteristics of these "in-between" spaces, the transitional, layered, temporal, and dynamic are explored. Liminality is then universal, as it becomes a transcendental experience for the character, who is situated in an in-between space that creates a sense of awakening, separating them from conventional life and inputting different alternative social interactions. In The Discreet Charm of the Bourgeoisie, this liminal space is adherent in dreams, which are embedded in a lingering state of limbo. This limbo is associated with a surrealistic paradigm that recognizes levels of social, cultural, and psychological changes associated with early modernity. These between spaces are integral to the human processes of ritual and transformation and can be interpreted as a painful passage between alternative states that involves "the removal of previously taken-for-granted forms and limits" (Szakolczai, 2009, p.148). The horror that occurs in this state of limbo, the horror of the bourgeoisie when the characters realize that the material world around them is turning upside 
down in Bunuel's cinema of deception, creates a pattern of rites also seen in Victor Turner's Ritual Process (1969). Turner concurs that in such liminal spaces, a person's sense of identity dissolves, creating disorientation but also the possibility of new perspectives (Szakolczai, 2009, p.156). What these characters fear is that this liminal space might become permanent for them. From the ambassador's fear of persecution to the simple breakdown of their normal course of daily life, such as no tea or coffee being available at a tearoom, the bourgeois' fear of losing all traces of their culture is a recurring theme in Bunuel's film.

The concept of life as a dream is explored through the structure of the film's complexity. As Steven Kovac describes in his review of the film in Film Quarterly, the spectator is faced with the gaze of "a group of people who are trying to get for dinner and are prevented from doing so by an extraordinary series of unforeseen circumstances (Kovac, 1972, p.14-17). The circumstances that disrupt the ritualized event of dinner are overshadowed by the "surreal absurdity of movement." In this case, the period of a ritual, where the person is physically and/or symbolically beyond the normal boundaries of society is not only disrupted by circumstances but also by dream-realism and the surreal. The position in which the characters find themselves through the third space creates a dialogue between two entities: one, which represents fear and loss, and the second, which represents stature and power. The purpose of this study is to examine 
the use of liminal space and Surrealism to identify the role of the bourgeois and their fears through the lens of Bunuel.

By exploring their liminal space becomes "transparent thresholds, separation, and connection at the same time, enclosing a third space (Bhabha, 2011). Thus, the "reassessment of identity" is situated as a third space, interpreted as limbo.

Death, Dreams and the Bourgeoisie

In the early 1920s, under the leadership of André Breton, Surrealism explored the intuitive decorum of fantasy and dreams. The philosophy behind the movement analyzed the human condition and its pursuit of liberation. Although contradictory in nature, the Surrealist movement and Marxist political theory both shared similar agendas - to escape the suppression of a capitalist society under the guise of civilization and progress (Breton, 1972) Marxist analysis of this human condition explained that the proletariat, the sufferer, inevitably becomes an "appendage of the machine" and falls under the shiny new boots of the bourgeois elite (Marx, 1994). Therefore, the oppression of the mind, in its material and imaginative forms, must be liberated, and the surrealist and the communist strive for both freedom of the mind and human form. The Surrealists aimed to find resolution for the diametric oppositions of "sleeping and waking, dream and action, reason and madness, the conscious and the unconscious...the subjective and the objective" (Breton, 1978, p.1.). The artistic practice of the Surrealists combined both surrealist metaphysics 
and Marxist material reality, which produced a physical representation of Surrealism's imagined objects (Balakian, 1954). These dream-like objects, known as les objects orniques, mediate the contradictory extremes of both reality and dreams. Thus, by embodying both, these objects become fundamentally concrete and material as objects and, through Surrealist art, depict the inner hallucinations of the mind (Balakian, 1954)

The quandary between surrealism and communism in their respective realities reminds us of the phrase "the enemy of my enemy is my friend," as one represents a fantasy, and the other operates through historical materialism. However, in this case, the surrealist form exists in a state that not only denotes the "fortuitous meeting of distant realities" but also is ontologically acceptable to both fantasy and historical materialism (Balakian, 1954).

In The Discreet Charm of the Bourgeoisie, it is telling that Bunuel's representation of the bourgeois replicated the way he viewed the petit bourgeois classes, some of which had "adopted surrealism only after finishing their university studies and experimenting with a bohemian phase characteristic of most artists and poets throughout the capitalist epoch" (Klaus, 2016, p.10). Marx noted that these types of bourgeois elites "have raised themselves to the level of comprehending theoretically the historical movement as a whole" (Marx, 1994, p.167). Due to the foundation on which the fundamentals of surrealism were structured, the surreal aesthetic could 
not immediately oppose the ruling class, as they, too, were affected by social conditions that exist in the capitalist power structures and interests. Therefore, instead of combating these capital interests head on, the understanding of the surrealistic mind was established in the "infiltrative nature of bourgeois oppression" (Klaus, 2016 p.11). By acknowledging this, surrealism separated itself from the communist agenda through practice and principle, and the proletariat recognized the "standard of their bourgeois notions of freedom, culture, law...that these ideas are but the outgrowth of the conditions of your bourgeois production and bourgeois property" (Marx, 1994, p.172).

In the late 1920s, the surrealist movement drifted from its intuitive epoch and focused on a reasoning phase that espoused the introspective works of Sigmund Freud. Freud and the Surrealists shared a passion for investigating the world and the way humans perceived it, ignoring conventional perceptions and norms as defined by society. André Breton's Manifestoes, which explored the concept of automatism amongst other forms of expression, relies on the Freudian psychoanalytic techniques, research methodologies, and, of course, the interpretation of dreams (Breton, 1924). This proved to be a stable foundation from which Surrealism evolved.

By using these Freudian methods of investigation, surrealists were able to agree that somatic and organic stimuli contribute to the vivid causes of dreams, which in fact exhibit meaning beyond the sedative state (sleeping). The very definition of Surrealism exhibits the dogma of 
Freud's psychoanalytic approach, as André Breton defined in 1924 in the Manifesto of Surrealism, which explained surrealism as a "physic automatism in its pure state, by which one proposes to express - verbally, by means of the written word, or in any other manner - the actual functioning of thought. Dictated by the thought, in the absence of any control exercised by reason, exempt from any aesthetic or moral concern" (Breton, 1924, p.26). The hypothesis of Freud's tripartite psyche embodied the combination of gratification and repressed urges as textures of desire, and that the ego, which conforms to what society deems acceptable, continuously seeks approval, which is mediated by the super-ego, a moderator that navigates between the conscious and the unconscious, entailing guilt upon the proletariat. Bunuel played with these textures with the layering of the bourgeois characters and their dreams.

Freud (and the Surrealists) deconstructed this behavior through a process that he referred to as regression in his psychoanalysis, an act in which patients attempt to defend their egos so that they are able to fall into the pretext of socially accepted thought (Williams, 2016). The way that Freud inspired and provided confidence to Surrealists to explore the imagination allowed for the realm of fantasies, superstitions, and desires to occur in the real (Reuben, 2017 p.6)

To explain the state of dreaming, Freud used psychoanalytic concepts to theorize that when the mind is no longer influenced by the impressions of the day, the stimuli are no longer 
overwhelmed. As surrealists used idealism, outlined by the conscious and the unconscious state of mind, Freud theorized that "a dream looks upon the world in a light of strange idealism and often enhances the effects of what it sees by its deep understanding of their essential nature" (Freud, 2010). This "imagination" is able to be liberated from any authority of reason and control, and is able to position its psychic-like functionality into an absolute freedom. "Though dreamimagination makes use of recent waking memories for its building material, it erects them into structures bearing not the remotest resemblance to those of waking life; it reveals itself in dreams as possessing not merely reproductive but productive powers" (Freud, 2010).

These productive powers, which manifested in the visualizations of dreams, are not tainted by moral judgement or suggestion, and so surrealists were able to take these dream-images and develop "visual representations of thoughts, states, and dreams" and liberate an imagination that does not fall victim to the concept of reality (Reuben, 2017, p.8). "Surrealism used objects of art to break down the art barrier between the familiar and conventional and inner visions and as part of its broader aim to bring the unconscious and dream energy to the light of day" (Breton, 2002, p.277).

Following a less formal mode of psychoanalytic analysis, surrealists considered the interpretation of dreams to find various derivations of what the unconscious desires. This automatism, as Breton mentioned, disentangles emotions, where the psychic restitutes the external 
reality. This regression, which is pulled back to unveil the hidden, or the "pure" reality, is used in psychoanalysis by enhancing free association, which can lead to troubling thoughts, resistances, associations and patterns, which can be identified in the works of the surrealist painter. For example, in the works of Salvador Dali, a "paranoiac critical activity" takes place, where a sense of mêlée exists between the ego and the superego in front of an alternative world backdrop. The landscape represents the different parts of his psyche, and the super-ego develops a sense of satirelike humor, which leads to an endearment of catharsis for the painter, as a means to confront or perhaps adapt to the oppressive nature of his society (Breton, 2002).

The differences between Freud's psychoanalytic methods and Surrealist thought lies in how they responded to the "nonsensical and random aspects of the mind and dreams" (Reuben, 2017, p.13). Freud did not acknowledge a direct translation between dreams and waking consciousness. Surrealists, on the other hand, used the interpretation of dreams as a stepping-stone to highlight the consciousness and its perceptions. Their aim was to highlight the importance of dreams as something highly valuable and important in an effort to view society and its structure. Freud avoided any social or political interference, focusing on the biological, rather than the hypothetical. 
This caused a division among the surrealists who relied on psychic automatism and those who worked hand-in-hand with the French Communist Party (Watson \& Polizzotti, 2002). Again, the relationship between communism and surrealism became eminent, one that relied on the individuals' own thoughts and consciousness rejecting external realities, the other dependent on "collective action and uniform" (Reuben, 2017, p.16). Breton's surrealism essentially endorsed a proletarian revolution, the liberation of humans equals the liberation of the mind, justifying the political, which "we consider that this action has its own method in dialectical materialism...we hold the liberation of man to be the sine-qua non-condition of the liberation of the mind, and we can expect this liberation of man to result only from the proletarian revolution" (Breton, 2012, p.120).

This hypothetical, however, contributed to the relationship between dreams and the dead. One reference to death is found in the work of Surrealist Andre Masson. Masson's experience of the First World War led to psychological trauma and the publication of Memoire du Monde (1974), a recollection of the horrors he experienced during his time in warfare. Masson's canvases exhibited an aesthetic of trauma and violence, replicating the graphic images in automatic drawings. Masson's time at the battles of Somme not only affected his art but also in his graphic accounts of the war, one which he referred to as "the suicide of Europe." 
I shall sing of the stupendous fatigue of the soldiers, of the unwanted consequences of action, of the scared human wrecks abandoned on the battlefield. Above all, the physical misery of human beings become hideous: covered with mud from head to foot for a week and often longer, of "sojourn" on the front line...many of us unable to wash off the carapace of earth and excrement. Lacking water to drink...like accompaniments, the pounding of artillery and the increasing fear, the one of "gas alert" being not the least distressing (Hubert, 1992).

The images of the dead emerged in juxtaposition with the post-war years in paintings such as The Cemetery (1923) where the image focuses on the mutilated body parts (representing the slaughtered of the First World War) "displaced into the branches and stems of a soft, anthropomorphic forest which stretches out of the shadows of death towards the warning sun" (Baxter, 2016). What Masson and the surrealists tried to make evident in their illustrations of the dead, was that "man-made edifices which are constructed in order to contain historical memory can no longer hold because death will always (and paradoxically) spring back to life and force a confrontation (Baxter, 2016). This process of remembrance, to which the Surrealists strived to give meaning, included a sense of experience loss and giving form to a series of "unconscious memories." 
Extending the notion of Surrealists' fascination with death and trauma, it is important to highlight one of the main collective methods applied by early surrealists, called cadaver exquis, the exquisite corpse. These collective exercises, explored as a game, were a particularly important part of their artistic production and explored several methods of research, such as collective creation, ludic activity, and psychoanalysis. Inspired by the events of the First World War, the exquisite corpse games "embodied Surrealist principles such as automatism, chance humor, and thought transmissions" (McShane, 2000, p.87).

During this time, as published in the second series of Littérature, a literary and Surrealist magazine edited by Breton where the Period of Sleep was explained. Uncovered by the tract entrée des mediums, the Period of Sleep was an extended look into the subconscious operations of the surrealist mind based on principles of hypnosis and trance induced automatism. Violence prevailed during these experiments, with members attacking one another under hypnosis, so it is unsurprising that the surrealists would incorporate the theme in their work. The horrible and traumatic effects of World War One lingered in the trances of these sessions, and it was not until 1924 that the link between the Surrealist games and WWI was made palpable. 


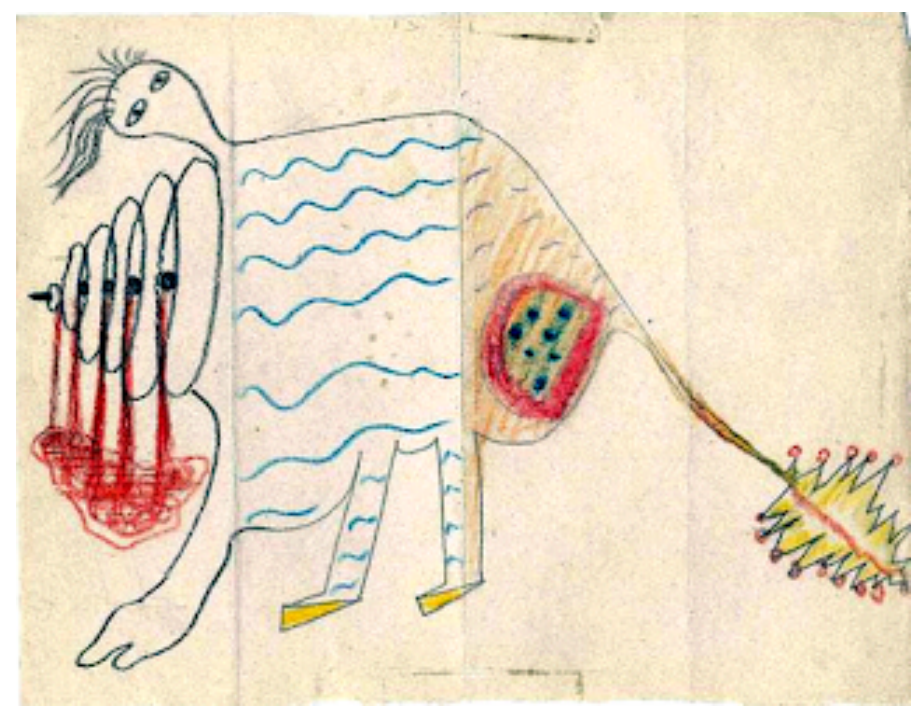

Figure 1: An example of a cadaver exquis, by André Breton, Camille Goemans, Jacques Prevert, and Yves Tanguy.

Games such as the cadaver exquis were a means to evade the allusive ennu, a term which was derived by Breton, which meant delicate monster. This monster haunted the Surrealists' psyche like the plague, following them to the depths of their adjusting lives in the bourgeois society. From mania to lethargy, "the monster of ennui was for the Surrealists, a very real and terrifying thing," and "there is, then, an element of fear for one's will to live that exists in the terror inspired by excessive ennui" (McShane, 2007, p.88-89). To put into simple terms, ennui represented terror and association with death, a disease of the mind that overtakes one's functional desire to live and can also be translated to psychoanalytic terms of post-traumatic stress disorder. What the Surrealists suffered in the war had followed them back home, and by combining their collective experiences, that used games such as cadaver exquis not only to run away from this 
delicate monster but to "research into the collective unconscious" (McShane, 2007, p.88-89). By partaking in these drawings, a form of lucid experiment, violence, death, and trauma became the pillars of the Surrealist project and the game of the exquisite corpse should be viewed as an escape from ennui, in the sense that ennui was perceived as a death by not dying.

\section{The Liminal Architecture of the Bourgeois' Limbo}

The combination of the rites of death, dreams, and surrealism is prevalent in the liminal structure of the mise-en-scene and locations used in the dream sequences of The Discreet Charm of the Bourgeoisie. Bunuel's use of unexpected juxtapositions revealed his intention to not allow the bourgeois to enjoy a hospitable dinner.

What the opening sequence of the film presents the audience through its liminal space

of death is reminiscent of an old folk joke about the hidden corpse. This cadaver exquis is reversed in the sense of its delivery, depicting the bourgeois archetype's response to death as "business as usual." Starting with a misunderstanding, the guests arrive at their dinner arrangement only to be met by their host, who was not expecting them. After a short conversation, the guests and the host decide to eat out for dinner. Examining the dichotomy of the bourgeois and the "peasant man," the allegory of death as represented here begins in the verbal pas-de-deux between $\mathrm{M}$. Thevenot, one of the guests, and the waitress of the auberge, who appears hesitant to admit the bourgeois party. 
By the end of this scene, the characters become well situated in the third space. Unknown to them, the body of the owner of the Auberge is laid out in the room next to the dining hall; the scene hints at the bourgeois role of "man as carnivore." The formalist function of this scene acts as a "discordant reality based on the juxtaposition of instinctively felt opposites" (Osbourne, 2016, p.18) as the bourgeois troupe complains about the lack of expensive wine, "maintaining the social façade before passing through the façade of the Auberge" (Osbourne, 2016, p.19).

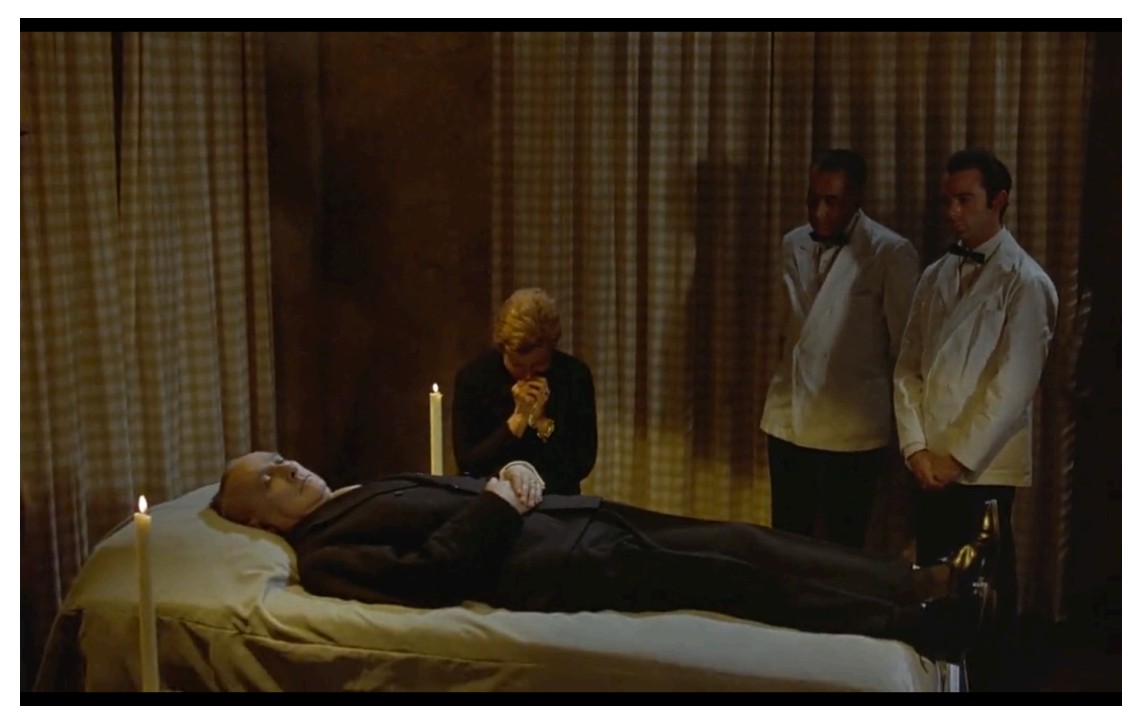

Figure 2: The corpse of the owner of the Auberge.

Bunuel seeks liberation of mind not through the bourgeois troupe, but through the secondary characters, interweaving the pious-like emotions of the bourgeois into a limbo state in which the hallucination of the dead exists in its entirety. When the bourgeois ladies visit the tea room they find themselves in an unusual dilemma. There is no tea or coffee, which robs them of 
their basic necessities. A soldier, who is overcome by guilt and seeking retribution, interrupts their dilemma and provides a confessional-like intercut, a haunting of his childhood repression and torture. As we cut to a flashback, a younger soldier is being told by his father that he should prepare himself for the military. As the young boy leaves the room, he finds brief happiness in the hallway. What is an uncomfortable space between the living and the dead, an apogee of the supernatural, is the young boys only refuge, as he dances away, bouncing from wall-to-wall. As he reaches the end of his brief liberation, the ghost of his mother appears, instructing him to poison his father. Not only do we see the stark contrast between the representation of the bourgeois in the tea-room, we find similar elements in his "father's" character, a bourgeois feudal. The appearance of the soldier's biological father, with his face mutilated, clearly a fallen soldier, exhibits the sacrifice of what honor truly is. Yet, the three women he confides in can say nothing, most likely still reveling in the fact that there is no tea or coffee available. This dream is lost in limbo, as is the helpless soldier.

This disruption can be juxtaposed with another military interruption, as the colonel and his men base themselves at the host's house in preparation for "maneuvers." Once again, we see another tormented soldier recalling a dream. In the atmosphere fogged atmosphere of limbo, the sergeant runs into two of his old friends and a lost love, all of whom are walking the lines of the supernatural, not knowing they are indeed dead. The street itself is an indefinite space of searching 
for something that is not in fact there. Although told separately, the dreams and memories of the lieutenant and sergeant are similarly juxtaposed in a third space. For the lieutenant, this is represented by the hall, and for the sergeant, by an empty street filled with shops, both of which lead to the ghosts of their pasts and their own frightening fate.

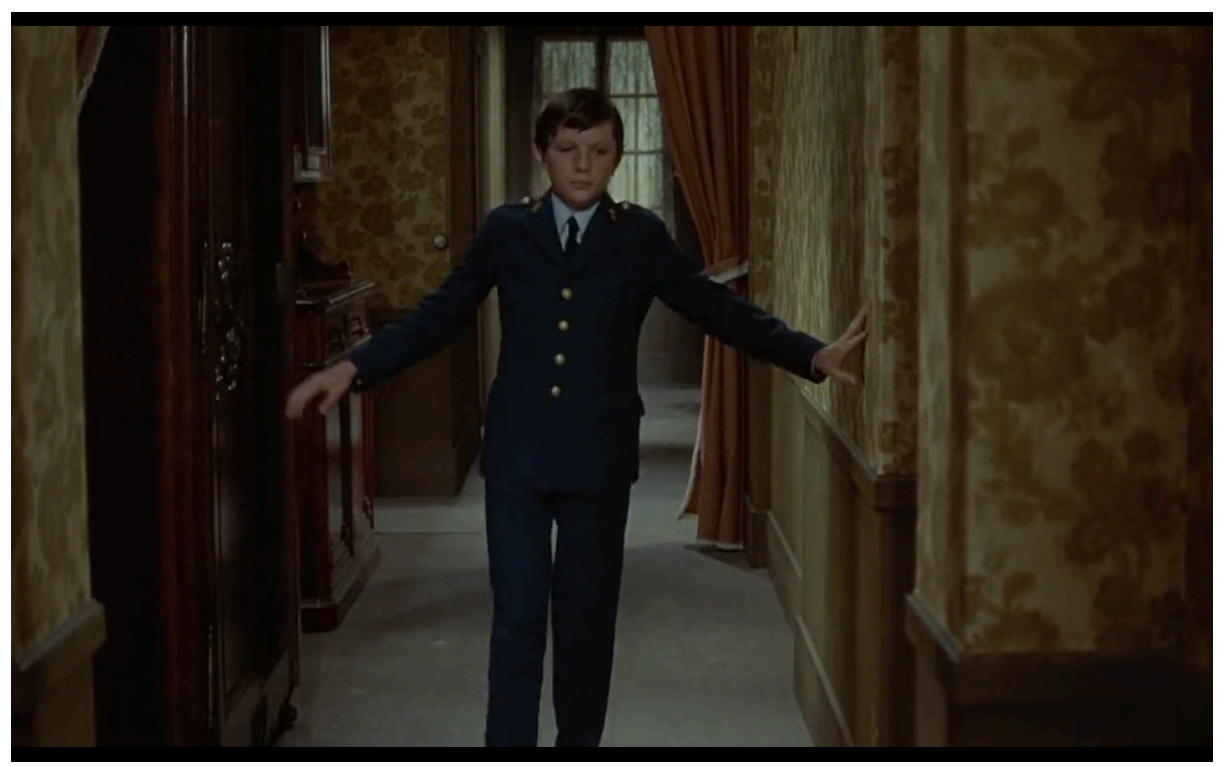

Figure 3: The young soldier as a kid walking down the hallway of death. 


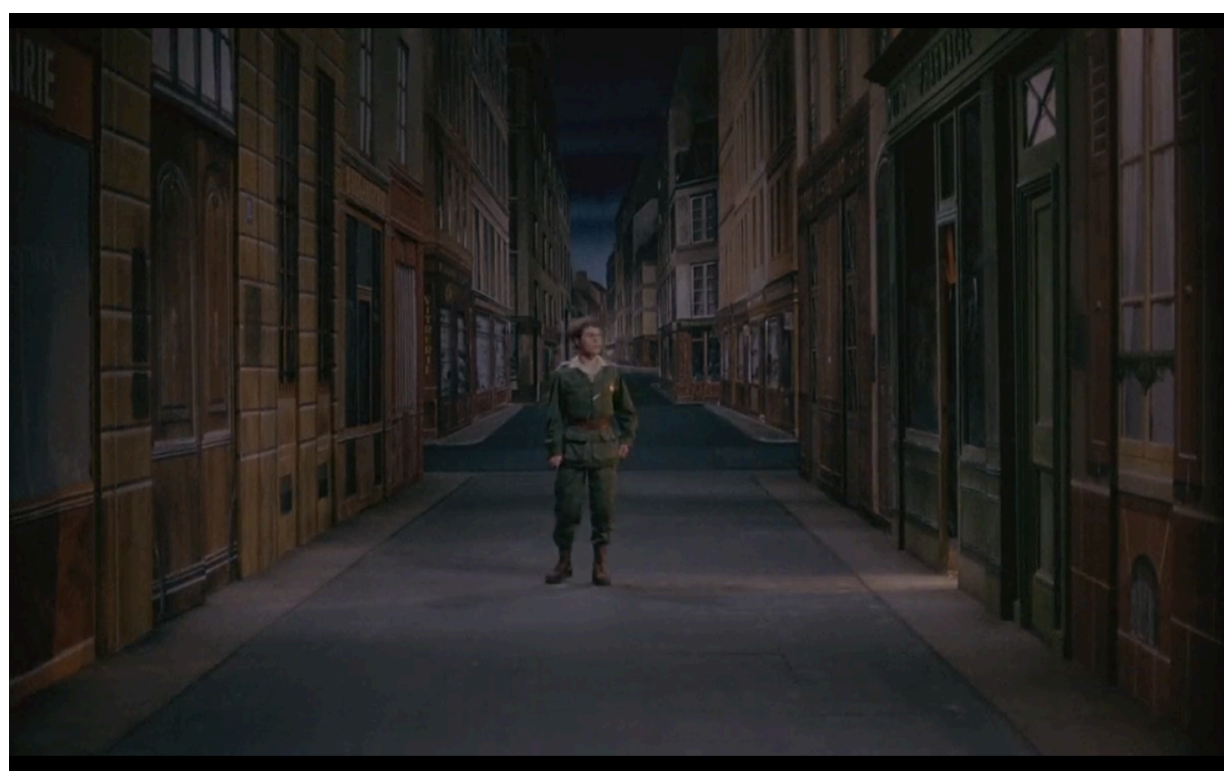

Figure 4: Another soldier, alone in the empty street, visited by his memories which include his dead friends and an unrequited love.

After being invited to the colonel's home for dinner, the guests arrive and begin exploring the numerous war artifacts their host owns, such as a hat worn by Napoleon in battle. After sitting down to await their meal (without the host or his wife in sight), the servants bring out the prepared meal composed of "plastic chickens," which fall to the ground. Regardless, the servants continue to serve the faux chickens, with the guests noticing and briefly commenting on whether it is a practical joke. That is as the extent to which Bunuel allows the guests to engage in this dream-realism before they continue to converse with one another. Suddenly, the curtain behind them opens and they are confronted with an awaiting audience as they realize they are on stage. Finding themselves in a position of "theatre-verte," our guests are overpowered by the urge to perform for an increasingly impatient audience. This exposure, in which the bourgeois is situated 
as puppets of sorts, faced with performing in front of the audience, shows the weakness or perhaps flaw in the class-system structure. In the face of exhibitionism, our guests' "inner emptiness" has been exposed, and Bunuel reminds the viewer that "all these gatherings have been social performances" (Jones, 1999, p.46). By combining stage fright and anxiety with the preconceived idea that the guests know their lines by heart, the stage transforms into a third space where their exposure turns into the fear of becoming one with simple peasants, in the lieu of the capitalistic system they have created.

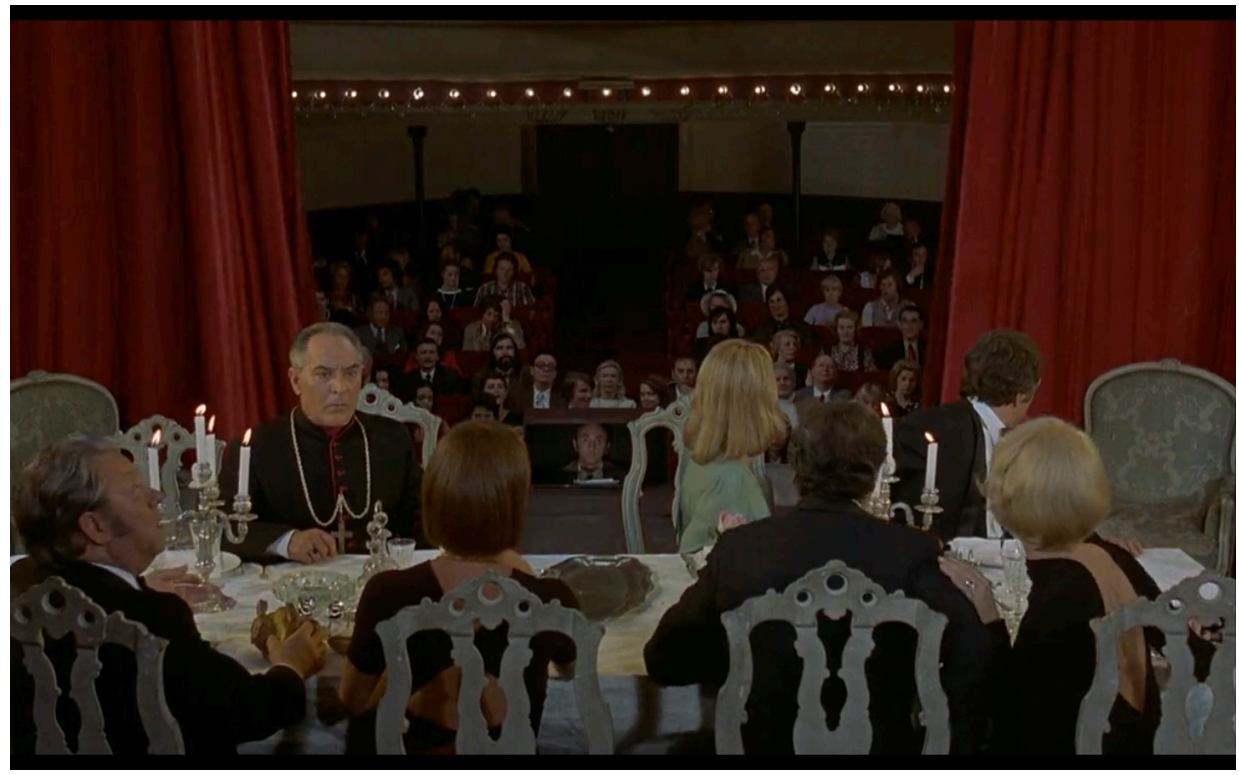

Figure 5: Surprise! The bourgeoisie find themselves in their own "theatrical" dreams, being looked at and judged by strangers in an uncomfortable setting. 
As it becomes nearly impossible to distinguish the boundaries of realities and dreams, we reach the climax of these disruptions during the ambassador's dream. Gangsters, who are a part of a Marseille gang, interrupt this gathering, claiming to be the rivals of the three bourgeois men in the heroin business. They proceed to gun down the guests, execution style, while the ambassador finds cover under the dining table. All the dream-sequences lead up to this apocalyptic event, facilitated by the ambassador's greed and hunger. This is translated in not only his cowardice as shown not only by his abandonment of his friends to hide under the table but also by his continuous hunger for power. Even as he sits there, defeated, the ambassador reaches out from beneath the table to grab a piece of lamb, thus showing that he is not yet satisfied, whether psychically or mentally.

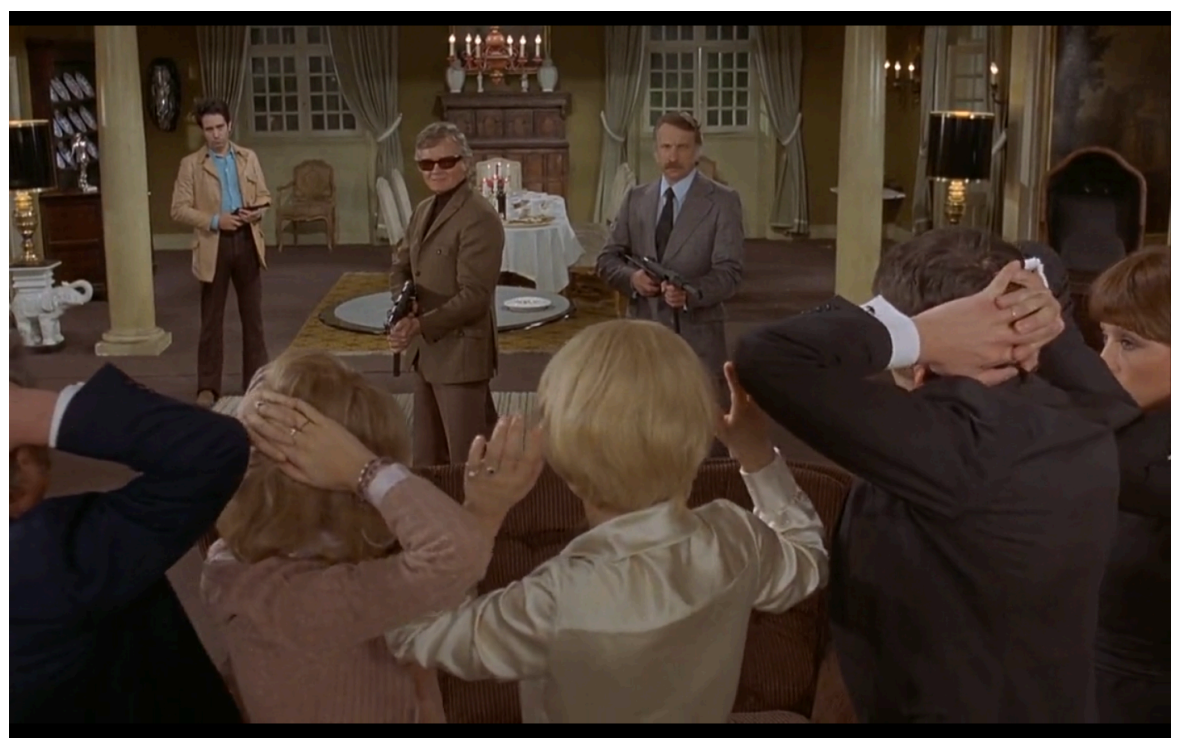

Figure 6: The Massacre! The Ambassador's dream, as his rivals arrive and gun down the guests. 
What we gather from the dream-realisms is several illustrations of how a series of dinner parties "can do as little to preserve their participants from the emptiness which society has sowed within their hearts as communing with nature could do to redeem the Victorian middle class from its materialism" (Durgant, 1975, p. 52). The liminal limbo of the bourgeois blossoms into the fear of the material through a raucous atmosphere. These dinner parties conspire to be a form of potlatch, although we never see one fully completed, as the open road scenes break in, which show the group continuously walking on several occasions in the film. Perhaps this particular liminal space of emptiness and uncertainty is a meeting point where their lives intersect. It is noteworthy that Bunuel's own feeling towards open spaces lends its hand to this form of constraint; perhaps the horror of this open space is the never-ending road to limbo.

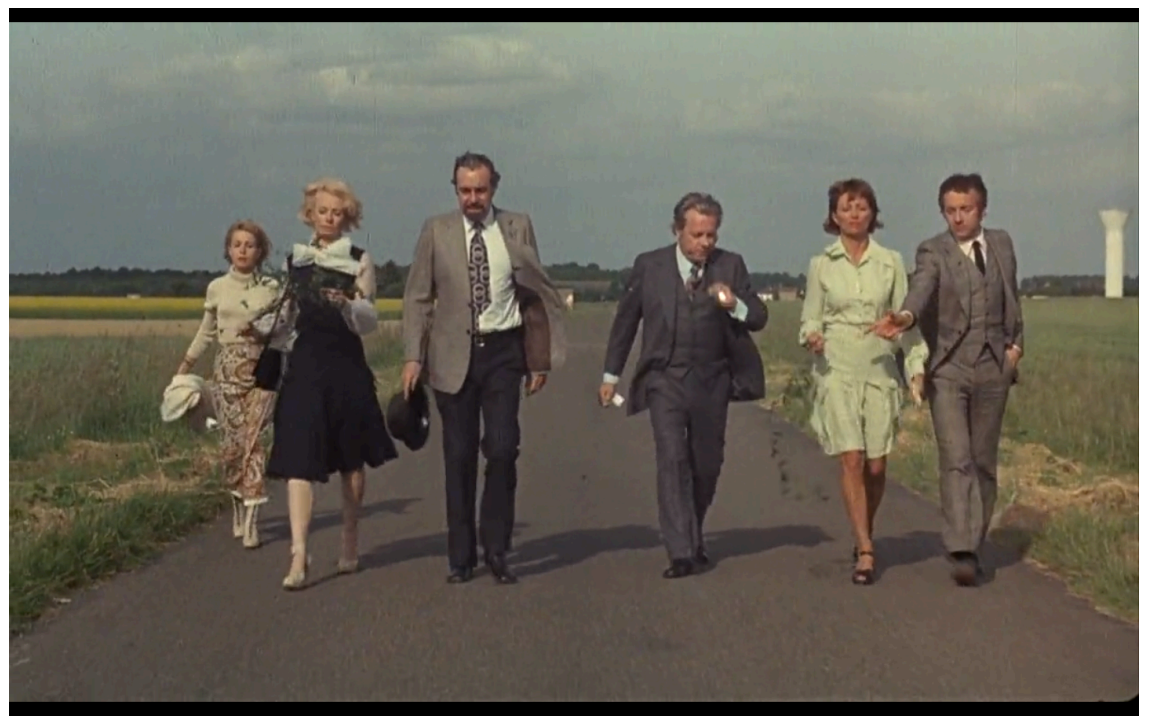

Figure 7: The never-ending road of limbo as the guests never reach their destination. 


\section{Conclusion}

In this film, dreams as liminal spaces represent the limbo state of the bourgeoisie. The third space created in between is where these guests precede, aimlessly haunted by their own social transparency. The idea of liminal space is not only considered to be the dreams represented in the narrative but also as the notion of liminal limbo, a cursed artifact of the bourgeoisie and the result of a revolution of the mind. What the film delivers is a form of irony over military paradoxes, a sort of gratification of Marxist anarchism that folds into the deck of chaos. Bunuel's homage to the suffering and trauma that the Surrealists endured during the First World War is exhilarating in a satire of bourgeois chicness, which whether the loss of material benefit or performance anxiety, is nowhere near the same level of the suffering that the soldiers withstood. A total of "nine instances of interrupted or no-existent meals" (Osbourne, 2016, p.17), including the soldier's dreams and memories, the "theater" dream and of course, "the massacre." What these dreams share is that even though these characters adhere to bourgeois etiquette, changing circumstances prove quite disruptive and threats may arise even from those who are intended to protect them and are suffering in their own nightmare. The heretical cinema of Bunuel proclaims that his films are indeed representations of morality. The bourgeois and their relationship with materialism are identified as a hierarchy of damnation, a combination of greed and heresy, lost in limbo's third space. 


\section{BIBLIOGRAPHY}

Balakian, A. (1959) The Surrealist Object. In Surrealism: The Road to the Absolute, 170-209. Toronto: Clarke, Irwin \& Company Ltd.

Baxter, J. (2016) The Persistence of Surrealism: Memory, Dreams, and the Dead." In S. Gross (Ed.) Memory in the Twenty-First Century: New Critical Perspectives from the Arts, Humanities, and Sciences (pp. 51-56). London: Palgrave Macmillan.

Breton, A. (1972) Manifestoes of Surrealism. Ann Arbor: University of Michigan Press.

Breton, A. (1978) What is Surrealism? Selected Writings, edited by Franklin Rosemont. New York: Monad Press.

Breton, A. (2002) Surrealism and Paintings. ArtWORKS ed. Boston: Museum of Fine Arts.

Breton, A. (2012) Theories of the Avant-Garde Theatre: A Casebook from Kleist to Camus. ed. Bert Cardullo. Scarecrow Press, p.120.

Durgant, R. (1975). The Discreet Charm of the Bourgeoisie. Film Comment 11(3): 52.

Freud, S. (2010) The Interpretation of Dreams: The Complete and Definitive Text.

Hubert, R. (1992) Surrealism and the Book. Reprint ed. Berkeley: University of California Press,

Jones, J. (1999) The Picaro in Paris: The Discreet Charm of the Bourgeoisie and the Picaresque Tradition. Journal of Film and Video, 51(1), 42-55.

Klaniczay, G., and É. Pócs. (2005) eds. Communicating with the Spirits. Vol. 1 of Demons, Spirits, Witches. Budapest: Central European University Press.

Kovacs, S. (1972) The Discreet Charm of the Bourgeoisie by Luis Bunuel. Review of The Discreet Charm of the Bourgeoisie, by Luis Buñuel. Film Quarterly. 26(2), 14-17. 
Klaus, R. S. (2016). Surrealism, Communism, and the Pursuit of Revolution. Black \& Gold, 2(1), https://openworks.wooster.edu/blackandgold/vol2/iss1/1.

Marx, K. (1994) The Communist Manifesto. In L. H. Simon (ed.) Karl Marx: Selected Writings. Indianapolis: Hackett.

McShane, M. (2000). Exquisite Corpses: Representations of Violence in the Collective Surrealist Unconscious. Paroles gelées, 18(2), 87-98.

Noll, R., Achterberg, J., Bourguignon, E., George, L., Harner, M., Honko, L., ... \& Winkelman, M. (1985). Mental imagery cultivation as a cultural phenomenon: The role of visions in shamanism [and comments and reply]. Current Anthropology, 26(4), 443-461.

Osborne, J. (2016) Pierce, Deleuze and the Play of Perception in Luis Buñuel's The Discreet Charm of the Bourgeoisie." Self-published, ResearchGate. DOI: 10.13140/RG.2.1.1839.0646.

Reuben, A. (2017). Surrealism's Freudian Foundation. Self-published, Academia.edu.

Rivere, J. (2009). Deaths, Dreams and the Disorderly Dead: Liminality and the Discernment of Spirits in Early Modern England. In W. A. Christian, Jr. and G. Klaniczay (Eds.) The "Vision Thing”: Studying Divine Intervention, (101-134). Collegium Budapest Workshop Series.

Schmitt, J.C. (1994). Ghosts in the Middle Ages: The Living and the Dead in Medieval Society. Chicago: University of Chicago Press.

Szakolczai, A. (2009). Liminality and Experience: Structuring Transitory Situations and Transformative Events. International Political Anthropology, 2(1), 141-172.

Taylor, S. W. and M. Polizzotti. (2002) Surrealism and Painting. Boston, MA: MFA Pub, Print.

Turner, V. (1967). The Forest of Symbols: Aspects of Ndembu Ritual. Ithaca: Cornell University Press.

Williams, R. (2016) Psychoanalysis. Magill's Medical Guide, Ipswich, Massachusetts: Salem Press. Gale Virtual Reference Library, Research Starter. 